\title{
Article \\ Discussion on the Purchase Factors and the User Demands of Electric Scooters from the Perspective of Consumers' Life Style-A Case Study on Gogoro
}

\author{
Jui-Che Tu ${ }^{1}$, Xi-Hui Jia ${ }^{1,2, * \mathbb{D}}$ and Ting-Jen Yang ${ }^{1}$ \\ 1 Graduate School of Design, National Yunlin University of Science and Technology, Yunlin 640, Taiwan; \\ tujc@yuntech.edu.tw (J.-C.T.); m10630003@gemail.yuntech.edu.tw (T.-J.Y.) \\ 2 School of Mechanical Engineering, Yangtze University, Jinzhou 434023, China \\ * Correspondence: xavier@yangtzeu.edu.cn; Tel.: +886-981-040-186
}

check for updates

Citation: Tu, J.-C.; Jia, X.-H.; Yang,

T.-J. Discussion on the Purchase

Factors and the User Demands of Electric Scooters from the Perspective of Consumers' Life Style-A Case Study on Gogoro. Processes 2022, 10, 395. https://doi.org/10.3390/ pr10020395

Academic Editors: Tsai-Chi Kuo and Yu-Chung Tsao

Received: 17 January 2022

Accepted: 17 February 2022

Published: 18 February 2022

Publisher's Note: MDPI stays neutral with regard to jurisdictional claims in published maps and institutional affiliations.

Copyright: (C) 2022 by the authors. Licensee MDPI, Basel, Switzerland. This article is an open access article distributed under the terms and conditions of the Creative Commons Attribution (CC BY) license (https:// creativecommons.org/licenses/by/ $4.0 /)$.

\begin{abstract}
With the development and popularization of the concept of a sustainable environment, the green energy industry represented by electric scooters has entered a vigorous development period. However, consumers are reluctant to buy electric scooters, resulting in low sales, which is limiting the development of the electric scooter industry. Therefore, from the perspective of different consumer life styles, this study explored the impact on the purchasing decisions and user demands, so as to inform design strategy for the development of a sustainable electric scooter industry. This study adopted the methods of expert interview and questionnaire survey, used the self-made consumer life style and electric scooter product attribute scale as the research tool, and carried out quantitative analysis with the help of statistical software. It showed that compared with consumers' awareness of environmental protection, product performance is the key factor that attracts consumers to buy electric scooters. More than consumers' awareness of environmental protection, our study showed that product performance is the primary determinate of a consumers's decision to purchase electric scooters. The consumer of the electric scooter can be categorized into three life style groups: "brand-conscious group", "environmental and cost saving group" and "trendy adventurers group". Outside of the "environmental and cost savings" group, the least important attribute that drive purchasing decisions was environmental sustainability. This can also inform more effective governmental policies and education to promote greater environmental protection. Each life style consumer group prioritizes different product attributes; therefore, electric scooter manufacturers should view each group as distinct market segments and draw up different product design and marketing strategies.
\end{abstract}

Keywords: life style; electric scooter; environmental awareness; green consumption; Gogoro brand

\section{Introduction}

Faced with the increasingly severe global warming, the world has seen the energy crisis gradually emerging, and there is now international consensus on the importance of environmental protection and greater advocacy for green consumption practices. [1-3]. In order to reduce the impact on the environment, respect the limits on nonrenewable resources more and more consumers are beginning to advocate the concept of green consumption when making purchasing decisions [4,5] and are willing to take more substantive measures, such as "green transportation", for environmental protection [6-8]. At present, advanced countries are replacing traditional gasoline scooters with electric scooters that feature "low noise, zero emissions, energy savings, and environmental protection" as an important policy in industrial and environmental development. In Taiwan, scooters are one of the main causes of air pollution [9-12]. In this regard, the Environmental Protection Administration, Executive Yuan works for the EPA of Taiwan, not only continuously encourages manufacturers to produce environmentally friendly vehicles, but also publicizes the relative pollution emissions data of vehicles, and strives to improve urban air quality. 
To encourage people to buy electric scooters, the Taiwan government actively promotes policies related to green transportation and provides various subsidy programs [13,14].

In recent years, electrification has become the main development direction for scooters, but for more than a hundred years, electric power has been successfully applied to public transportation such as trams and subways. As both private and public electric vehicles have a long history, the main reason is that they are friendly to the environment, so they are still regarded as the main means to reduce greenhouse gas emissions in the future. Especially in urban areas, electric scooters are considered an important means to solve local environmental problems [15]. Compared with gas-fueled transportation vehicles, electric scooters are more competitive, because electric scooters greatly help to reduce emissions, and with the increasing use of renewable energy, electric scooters can help to improve power grid management [16]. The "DIGITIMES Technology Trend 2022" forum organized by Taiwan DIGITIMES Electronic Times put forward the development trends in the electric scooter industry, which is oriented towards four areas: flat supply chain, people-friendly pricing, popularization of charging stations, and intelligent design of electric scooters. At present, Taiwan is a region famous for its scooter market of scooters, and scooters are the main means of transportation for many people in daily life. Since traditional oil scooters are a major pollution source, it becomes an environmental protection issue in Taiwan, However, in 2015, due to the appearance of the brand Gogoro, the electric scooter industry has developed rapidly. Taiwan's electric scooter industry is booming, and Gogoro, a famous Taiwanese scooter brand, stands out and occupies about $90 \%$ of Taiwan's electric scooter market [17]. Based on its good market share, this study chose Gogoro as a research case.

The introduction of the Gogoro brand electric scooter has shored up the whole Taiwan electric scooter market, the electric scooter has been gradually accepted by consumers in the market, and the electric scooter industry is developing vigorously $[18,19]$. According to the statistics of Taiwan scooter market sales data from January to October 2021 (https:/ / motor.u-car.com.tw / motor/article/68372, accessed on 16 January 2022), Gogoro electric scooter sales reached nearly 55,000 vehicles, hitting a brand performance record, and occupying $80 \%$ of the market share of the electric scooter market, as shown in Table 1. With the support of governmental policies, the improvement in the performance of electric scooters, innovation in styles, and the increase of sales and maintenance bases, electric scooters are expected to further increase their market share in the future [20-23].

Table 1. Taiwan electric scooter sales data in 2021 (January-October).

\begin{tabular}{cccc}
\hline Rank & Brand & Cumulative Sales Volume & Sales Proportion \\
\hline 1 & Gogoro & 54,661 & 0.80 \\
\hline 2 & Aeonmotor & 6008 & 0.09 \\
\hline 3 & Kymco & 1381 & 0.02 \\
\hline 4 & eMoving & 1546 & 0.02 \\
\hline 5 & SYM & 544 & 0.01 \\
\hline 6 & Energy Moana & 557 & 0.01 \\
\hline 7 & PGO & 1594 & 0.02 \\
\hline 8 & Others & 359 & 0.03 \\
\hline
\end{tabular}

This study showed that sustainable development is significantly related to the value and behavior of green consumption. When products are demonstrated as green products in advance, some consumers' willingness to buy traditional products decreases and their willingness to buy green products will increase [24]. When consumers want to maintain a relationship with a product, the interaction, and connection between customers and brand products or activities can be significantly improved by three elements: conscious attention, enthusiastic participation, and social connection [25]. Therefore, among the various choice factors for consumers to buy green products, it is necessary to explore the relationship 
between varied consumers' life styles and their purchase intentions, and the relationship between consumers' demand for environmentally protective electric scooters with different life styles preferences [26,27]. This study explored purchase factors and user demands for electric scooters based on prospective consumers' life styles and discussed specific purchase factors and user demands that correspond with three identified consumer life style groups. The results of this study can be used as a reference for green enterprises to inform their manufacturing decisions and marketing strategies to gradually strengthen the demand for green products in the scooter market.

Previous studies lack in-depth discussion on the relationship between different consumer life styles and user demands. The existing research on life style mainly focuses on smart cities, health care, education system, and other fields [28-33], the research related to environmental protection issues mainly focuses on the ways to improve energy use in life style [34-36] and lacks research on the impact of consumer life styles on demand for green transportation options. Therefore, this study used life style preferences as a disturbance variable to explore differences in purchasing decisions and use demands due to that result in market segmentation. The main purposes of this study are as follows:

- Discuss and analyze the different life styles of prospective Gogoro electric scooter owners.

- Discuss and analyze the differences in purchasing factors for Gogoro electric scooters based on the different life styles of consumers.

- Discuss and analyze the differences in the user demands of Gogoro electric scooter based on the different life styles of consumers.

Furthermore, we put forward potential development directions for product design in the electric scooter consumer market according to these research results.

This study took "consumer's life style" as the basis of market segmentation, and distinguished different consumer groups by life style. The questionnaire survey was used to analyze and verify consumer preferences for product features and use demands in purchasing decisions that reflect these consumer life styles. Demographic characteristics and market segmentation based on consumer life style provide useful research for industries to develop innovative marketing strategies and to meet sustainability goals for the development of markets for green products.

\subsection{The Influence of Life Style on Consumption}

Life style was first put forward by psychologist Alder (1927), who believed that "Life style refers to the goals that individuals construct for themselves and the ways to achieve these goals, that is, life style is the way that people construct under a central goal". Kelly (1975) pointed out that life style is regarded as a cognitive structure system, so each group of people has its own specific life style, and a healthy life style refers to a set of external and internal conditions of human life, which is conducive to the long-term operation of all systems of the body, and is a series of actions aimed at maintaining and promoting health (self-protection behavior) to help people develop harmoniously. Life style is a systematic concept, which is the characteristics of a certain society or its group in life. These characteristics are enough to show the differences of this society or group and are embodied in a dynamic life style. Therefore, life style is the result of the forces of culture, values, resources, laws, etc. From the marketing point of view, consumers' buying, selling and consumption behaviors reflect the life style of a society or group.

With the sustained growth of economic income in emerging countries, people's life styles have changed significantly [37]. Studying the relationship between consumers' life style and consumption has become a meaningful academic topic, and various research results have been produced on specific issues related to life style, such as the relationship between life style and gender, economic income, health, and education [38-41]. It is found that there is no significant relationship between life style segmentation and product brand or country of origin when consumers make purchase decisions [42], but there are various factors that consumers consider when they make purchases. Besides branding, product attributes are also an important factor. What is the relationship between product attributes 
(such as appearance, performance, and environmental protection) and consumers' life style? At present, there is a lack of related research.

\subsection{The Consumption Market of Electric Scooters in Taiwan}

The world's first rechargeable electric scooters were launched at the end of the 19th century. The advantages of electric scooters being odorless, quiet, and having zero emissions compared to petrol-powered scooters propelled their development. Over time, with the massive exploitation of oil and international crude oil prices dropping, the cost to own oil-fueled scooters was lower than electric and electric scooters gradually lost market share. Since 1990, with greater calls for environmental protection, progress in technology, especially development in the battery industry, electric scooters have re-entered a period of rapid development. As time goes by, with the massive exploitation of oil, the price of international crude oil became lower and lower gradually, compared with electric scooters, the cost of fuel scooters is cheaper than electric scooters, therefore, electric scooters gradually lost their market. Since 1990, at the background of calling for environmental protection, with the progress of science and technology, especially the further development of the battery industry, electric scooters have re-entered a period of rapid development.

The scooter market in Taiwan has been developing for a long time. The data show that the per capita ownership of scooters has increased from 1.91 people in 2001 to 1.54 people in 2013. It is clear that the density of scooter ownership in Taiwan is close to its ceiling, as shown by flat growth in the domestic scooter market in recent years in Figure 1. Taiwan is a scooter-dominated region (https:/ / www.artc.org.tw / chinese/03_service/03 _02detail.aspx?pid=2453, accessed on 16 January 2022), and in 2021, almost everyone in Taiwan owned a scooter (https://udn.com/news/story/7266/5240218, accessed on 16 January 2022), so Taiwan has a mature and stable scooter consumer market. In recent years, the development of the market for oil-fueled scooters is almost full. Surprisingly, compared with traditional oil-fueled scooters, the sales of electric scooters continue to rise. According to the statistics of sales of electric scooters in Taiwan Province in 2018 by the Industry Bureau of the Ministry of Economic Affairs of Taiwan, since the Taiwan Executive Yuan approved the electric scooter industry development promotion plan in 2009, electric scooters have shown rapid development in Taiwan. By 2015, with the launch of the Gogoro brand electric scooters, the electric scooter market in Taiwan has seen record highs.

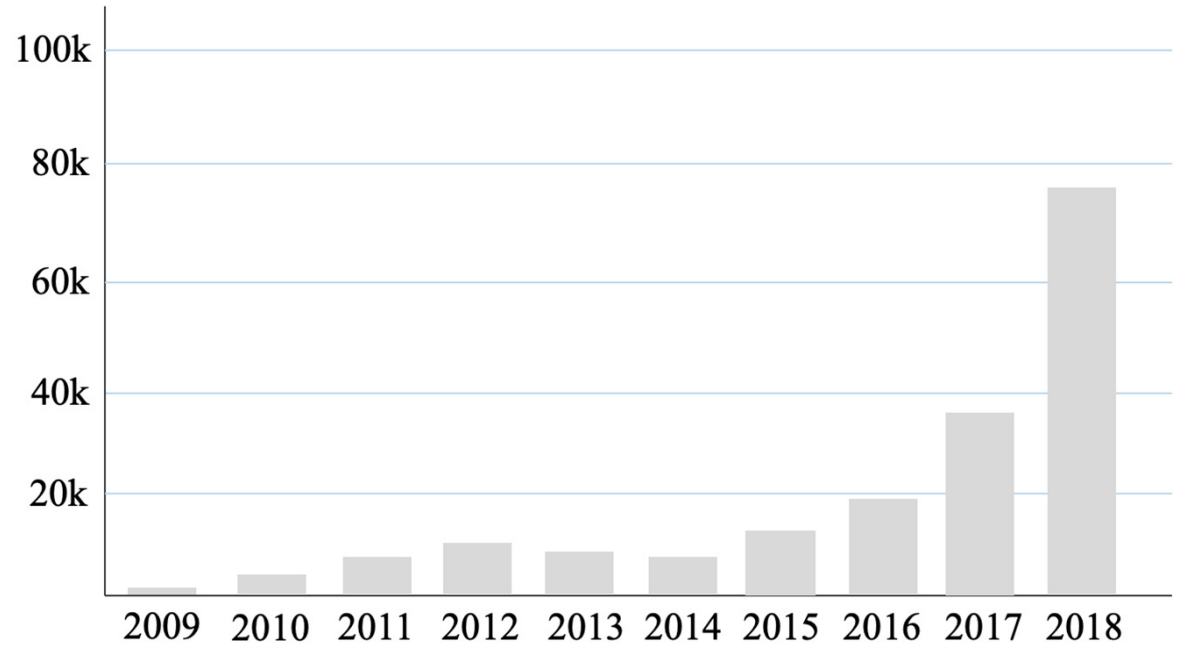

Figure 1. Sales of electric scooters in Taiwan over the years (2009-2018).

\section{Materials and Methods}

This study combined qualitative and quantitative investigation, including in-depth interviews and questionnaires. The research steps are divided into four stages.

The first stage includes literature collection and analysis. Through extensive reading, data collection, classification, collation, and analysis, the status of consumers' environ- 
mental awareness, life style, and green consumption behavior and the key to their mutual influence can be understood. Based on the summary and clarification of the data as the background of the follow-up study, it is expected to provide both academic and constructive basic research information.

The second stage includes an expert interview. With the help of interviews, the design criteria of the questionnaire structure were worked out. After summing up the experts' opinions, a prediction questionnaire was drawn up and distributed randomly. Thirty consumers over 18 years old who are willing to buy Gogoro were selected for prediction, and the prediction results were analyzed for the first time. By the reliability analysis results, the inapplicable items in the prediction questionnaire were deleted to ensure the completeness of the positive questionnaire.

The third stage is a formal questionnaire survey. the questionnaire survey was randomly distributed through an online survey. The respondents who had already purchased Gogoro electric scooters were excluded, and a total of 605 questionnaires were sent out to potential consumers. After deleting 7 invalid questionnaires, a total of 598 valid questionnaires were recovered. However, due to the fact that the proportion of consumers who are willing to buy electric locomotives was not known in advance when this study was conducted by online questionnaire survey, in the data analysis section, we only used the 353 valid questionnaires that indicated "Currently willing to buy Gogoro electric locomotives" for analysis. The remaining 245 questionnaires that indicated no intention to purchase a product will not be analyzed and discussed separately in this section.

Based on their purchase intentions, this study further analyzed the life style and purchase factors of consumers who are willing to buy Gogoro electric scooters.

In the fourth stage, the quantitative analysis tool of SPSS statistical software was used and included questionnaires were statistically analyzed by SPSS statistical software, the analysis results were summarized and discussed, and finally, the conclusions and suggestions were put forward. The research framework diagram is shown in Figure 2.

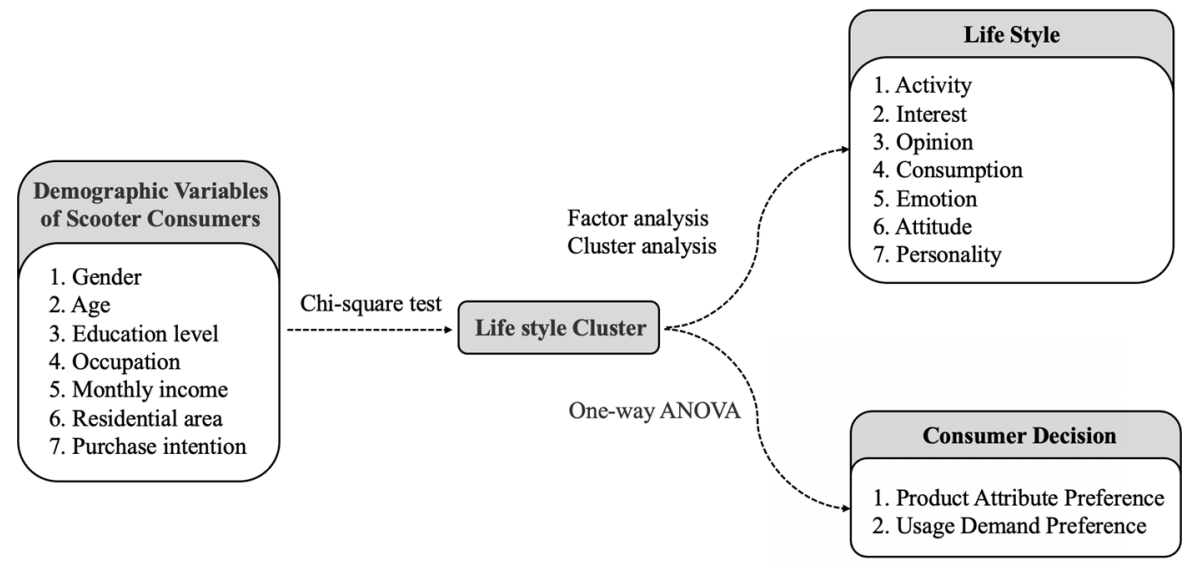

Figure 2. Research architecture diagram.

\subsection{Literature Analysis Method}

The first stage of this study discussed the related theories, studies, and cases of consumers' life styles and green consumption behavior. Through extensive reading, data collection, classification, collation, and analysis, the status of the consumers' environmental awareness, life style, and green consumption behavior and the key to mutual influences within life style groups can be understood. Based on the summary and clarification of the data as the background of the follow-up study, it is expected to provide both academic and constructive basic research information.

\subsection{Expert Interview Method}

The second stage of this study adopted semi-structured interviews, which include questionnaires or interview questionnaires, as well as rigorous and standardized topics 
of structured interviews. Although interviewers have certain control over the interview structure, they leave a large space for interviewees to express their views and opinions. In order to obtain in-depth and effective data and support arguments, this study collected data and completed other preparatory work in advance according to the results of literature discussion, aiming at important topics and market trends, including deciding research types and subjects, and drawing up an expert interview outline as shown in Table 2.

Table 2. Outline of expert interview.

\begin{tabular}{|c|c|c|}
\hline Category & Item & Interview with Experts \\
\hline \multirow{4}{*}{ Basic data of experts } & A-1 & Name of interviewee \\
\hline & A-2 & Academic background/research expertise \\
\hline & A-3 & Service units and main business responsibilities/teaching areas \\
\hline & A-4 & Job-related qualifications \\
\hline \multirow{5}{*}{$\begin{array}{l}\text { Green design and } \\
\text { consumer behavior }\end{array}$} & B-1 & $\begin{array}{l}\text { What do you think is the trend of consumers' preference and (green) } \\
\text { consumption behavior when choosing to buy electric scooters? }\end{array}$ \\
\hline & B-2 & $\begin{array}{l}\text { What do you think are the key factors affecting consumers' } \\
\text { purchase of electric scooters? }\end{array}$ \\
\hline & B-3 & $\begin{array}{l}\text { What do you think of the relationship between the trend of } \\
\text { consumers buying electric scooters and green consumption } \\
\text { behavior? If the consumers' life style is used to distinguish the } \\
\text { buyers of electric scooters, is there any real benefit in the research? }\end{array}$ \\
\hline & B-4 & $\begin{array}{l}\text { Do you think consumers' awareness of environmental protection } \\
\text { will affect their willingness to buy electric scooters? What is the } \\
\text { approximate degree of influence? }\end{array}$ \\
\hline & B-5 & $\begin{array}{l}\text { What do you think is the relationship among consumers' life style, } \\
\text { environmental awareness, and green consumption behavior? And } \\
\text { how will they influence each other? }\end{array}$ \\
\hline \multirow{3}{*}{$\begin{array}{l}\text { Present situation and development trend } \\
\text { of the electric scooter industry }\end{array}$} & C-1 & $\begin{array}{l}\text { What do you think is the current development and trend of the } \\
\text { electric scooter industry? }\end{array}$ \\
\hline & $C-2$ & $\begin{array}{l}\text { What do you think is the biggest disadvantage and threat facing the } \\
\text { electric scooter industry at present? And how to avoid this } \\
\text { threat/crisis? }\end{array}$ \\
\hline & C-3 & $\begin{array}{l}\text { What do you think of the sustainable development and green } \\
\text { consumption created by electric scooters? Does Gogoro's } \\
\text { innovative business strategies mean the real consumers' } \\
\text { purchase decisions? }\end{array}$ \\
\hline \multirow{2}{*}{$\begin{array}{l}\text { Characteristics and elements of electric } \\
\text { scooter products }\end{array}$} & D-1 & $\begin{array}{l}\text { What do you think is the difference between Gogoro and electric } \\
\text { scooters on the market today? What are the most attractive factors } \\
\text { for consumers to buy Gogoro? }\end{array}$ \\
\hline & D-2 & $\begin{array}{l}\text { Please briefly describe what design elements, criteria, or aspects } \\
\text { your ideal electric scooter must have. }\end{array}$ \\
\hline
\end{tabular}

\subsection{Questionnaire Survey Method}

This study was conducted by questionnaire survey. The questionnaire used was "Gogoro Consumer Life style and Purchasing Factor Preference Questionnaire", which consists of four parts. The first part is "Basic Consumer Data", the second part is "Life Style Scale", the third part is "Product Attribute Scale", and the fourth part is "Importance Ranking of Electric Scooter User Demand".

In the first part, the basic data of consumers mainly include gender, age, educational background, occupation, average monthly income, residential area, and purchase intention.

In the second part, the "Life Style Scale" was based on the AIO Scale of Half Life Style Dimension proposed by Plummer (1974) [43], with reference to the research questionnaires 
of Yu (2004), Yeh (2002), and Huang (2007), and then revised according to the actual needs of this study [44-46]. According to the feeling intensity of the subjects, the scale was divided into five options: "strongly agree", "agree", "neither agree nor disagree", "disagree" and "strongly disagree". There are 30 questions in this scale, and they were used to understand the life style of Gogoro electric scooter consumers. Through the construction validity evaluation, using the extreme group test, the item analysis of the life style scale was carried out, and one invalid item $(p<0.05)$ was eliminated, leaving 29 items with discrimination.

In the third part, the "Product Attributes Scale" was based on the product attributes proposed by Park, Jaworski, and Maclnnis (1986) [47], with reference to the questionnaires of Yu (2004), Chen (2005), [46,48], and then revised according to the actual needs of this study. The scale was analyzed by a five-point scale, which was divided into five options according to the feeling intensity of the subjects: "very important", "important", "fair", "unimportant" and "very unimportant". There are 27 questions in this scale, focusing on understanding the consideration factors of Gogoro electric scooter consumers when purchasing. Through the construction validity evaluation, using the extreme group test, the item analysis of the life style scale showed that all the questions are valid, leaving the questions with discrimination.

In the fourth part, the "Importance Ranking of Electric Scooter User Demand" includes commuting, travel and leisure, shopping, work and business use, environmental protection, transporting passengers, pursuing popular trends, attention seeking, building interest groups with other riders, and street racing. Using a 10-point scale, 1 is the most important and 2 is the secondary, ranking to the 10th in turn. From this table, the ranking of user demands can be measured.

\section{Results}

\subsection{Analysis and Induction of Expert Interview Data}

After literature discussion, this study interviewed experts in related fields, and sorted out and summarized the relationship and influencing factors among green design and consumption behavior, the electric scooter industry, and the characteristics and elements of electric scooter products by cross-comparison. The content of the expert interview was divided into three parts: green design and consumer behavior, present market conditions and development trends of the electric scooter industry, and characteristics and elements of electric scooter products. The interview contents of three experts and scholars were summarized and analyzed, and shown in Table 3.

\subsection{Analysis of the Types and Characteristics of Consumer Life Styles}

AIO scale was used in this study to understand the consumer's age, occupation, residential area, monthly income, and life style. By analyzing the sample structure of the life style items composed of the above-mentioned aspects, a basic profile of consumers can be formed. Factor analysis was employed to gather the highly related items into factors and explore the characteristics of consumers' life styles. Finally, group analysis can help find the group characteristics of consumers' life style clusters.

\subsubsection{Exploratory Factor Analysis and Reliability and Validity Test of Life Styles}

Based on the descriptive statistical analysis of consumers, exploratory factor analysis and reliability and validity tests of life styles were carried out. In this study, SPSS was used to evaluate the construct validity of the scale, and exploratory factor analysis was used to evaluate the convergence validity. The total reliability of the questionnaire life style scale in this study is 0.854 . The exploratory factor analysis was employed to extract the common factors of many variables in order to reduce the number of variables. The $\mathrm{KMO}=0.830$ and the significance of Pap's spherical test was $0.000(p<0.05)$, which reached a significant level, so the data presented are suitable for factor analysis. After passing the test, the common factors were extracted by principal component analysis in factor analysis. Seven factors were extracted by this scale, and the total explanatory variance was $59.400 \%$, which 
met the standard of over 50\%. The lowest eigenvalue was 1.384, which met the screening standard of over 1 . If there are enough questions, the items with lower factor load should be deleted first and then re-analysis could be conducted on the remaining questions to get the following results: the factor eigenvalues of the life style scale after deleting the items are shown in Table 4 , and the component matrix after the principal component analysis axis of the life style scale after deleting the items is shown in Table 5.

Table 3. Summarization and collation of expert interview data.

\begin{tabular}{|c|c|c|c|c|c|c|}
\hline Experts & & $\begin{array}{l}\text { Green Consumption } \\
\text { Behavior }\end{array}$ & & $\begin{array}{l}\text { esent Situation and Development } \\
\text { ids of the Electric Scooter Industry }\end{array}$ & & $\begin{array}{l}\text { Characteristics and Elements of } \\
\text { Electric Scooter Products }\end{array}$ \\
\hline A & 3. & $\begin{array}{l}\text { Consumers pay attention to the } \\
\text { quality of life, health, and } \\
\text { air pollution. } \\
\text { Market segmentation is made } \\
\text { according to groups with different } \\
\text { life styles. } \\
\text { The increase in willingness to buy } \\
\text { electric scooters is not purely related } \\
\text { to environmental awareness. }\end{array}$ & 2. & $\begin{array}{l}\text { The electric scooter industry needs } \\
\text { to be integrated according to } \\
\text { customer needs. } \\
\text { Product performance should be } \\
\text { improved, especially battery life } \\
\text { and safety, and supply convenience. } \\
\text { Leasing batteries, instead of owning, } \\
\text { reduces initial purchase costs and } \\
\text { provides many conveniently located } \\
\text { "swap and charge" self-service } \\
\text { battery stations. }\end{array}$ & 3. & $\begin{array}{l}\text { Gogoro's fee-based, convenient, and } \\
\text { widespread battery swapping } \\
\text { service stations offer. } \\
\text { Gogoro attracts consumers by } \\
\text { psychological, functional, pricing, } \\
\text { and brand factors. } \\
\text { Performance, safety, comfort, shape, } \\
\text { battery, and other factors are the } \\
\text { purchase expectations. }\end{array}$ \\
\hline B & 3. & $\begin{array}{l}\text { Consumers pay attention to } \\
\text { environmental protection, } \\
\text { advertising, word of mouth, } \\
\text { popularity, brand, and performance } \\
\text { Market segmentation is made } \\
\text { according to groups with different } \\
\text { life styles } \\
\text { The number of people who buy } \\
\text { electric scooters with environmental } \\
\text { protection is saturated. }\end{array}$ & 1. & $\begin{array}{l}\text { Pricing factors and governmental } \\
\text { policies are needed to promote } \\
\text { industry development and upgrade } \\
\text { supportive urban infrastructure. } \\
\text { Products need differentiation to } \\
\text { promote competition. } \\
\text { At present, local battery technology } \\
\text { is not well developed, and likely } \\
\text { there are not many people who are } \\
\text { willing to buy electric scooters } \\
\text { without government subsidies. } \\
\text { Gogoro wants to become an } \\
\text { "energy company". }\end{array}$ & 2. & $\begin{array}{l}\text { Gogoro's competitive advantages } \\
\text { are reflected in brand, performance, } \\
\text { battery, and modeling. } \\
\text { Manufacturers pay attention to } \\
\text { "electric scooters", not } \\
\text { just "scooters". }\end{array}$ \\
\hline $\mathrm{C}$ & 3. & $\begin{array}{l}\text { Environmental protection is just an } \\
\text { empty slogan and means to save } \\
\text { money unless consumers have a } \\
\text { clear understanding and } \\
\text { value sustainability. } \\
\text { Market segmentation is made } \\
\text { according to groups with different } \\
\text { life styles. } \\
\text { Environmental awareness has little } \\
\text { influence on purchasing behavior. }\end{array}$ & 2. & $\begin{array}{l}\text { Many consumers do not care and do } \\
\text { not understand green sustainable } \\
\text { development. } \\
\text { Governmental policy is the key } \\
\text { factor affecting industrial } \\
\text { development. } \\
\text { The leased battery charging and } \\
\text { swapping model, instead of buying, } \\
\text { is well suited for Taiwan. }\end{array}$ & $\begin{array}{l}2 . \\
3 .\end{array}$ & $\begin{array}{l}\text { Gogoro has a competitive advantage } \\
\text { in performance, appearance, battery } \\
\text { leasing, and charging service. } \\
\text { Gogoro attracts consumers by } \\
\text { pricing and experience. } \\
\text { Comfort, storage space, shape, } \\
\text { battery life, and convenient battery } \\
\text { leasing services are } \\
\text { purchase expectations. }\end{array}$ \\
\hline
\end{tabular}

Table 4. Post-axis interpretation variance and cumulative interpretation variance.

\begin{tabular}{llll}
\hline Initial Eigenvalue & & & \\
\hline Composition & Eigenvalue & $\begin{array}{l}\text { Explained } \\
\text { Variance \% }\end{array}$ & $\begin{array}{l}\text { Cumulative } \\
\text { Interpretation } \\
\text { Variance \% }\end{array}$ \\
\hline 1 & 3.640 & 15.166 & 15.166 \\
2 & 3.282 & 13.673 & 28.839 \\
3 & 2.444 & 10.182 & 39.022 \\
4 & 2.328 & 9.699 & 48.721 \\
5 & 1.869 & 7.789 & 56.509 \\
\hline
\end{tabular}


Table 5. Rotating component matrix.

\begin{tabular}{|c|c|c|c|c|c|}
\hline \multirow{2}{*}{$\begin{array}{l}\text { Life Style } \\
\text { Question Item }\end{array}$} & \multicolumn{5}{|c|}{ Composition } \\
\hline & 1 & 2 & 3 & 4 & 5 \\
\hline L1 & 0.785 & & & & \\
\hline L2 & 0.765 & & & & \\
\hline L3 & 0.740 & & & & \\
\hline L7 & 0.716 & & & & \\
\hline L4 & 0.713 & & & & \\
\hline L5 & 0.648 & & & & \\
\hline L6 & 0.554 & & & & \\
\hline L9 & & 0.814 & & & \\
\hline L10 & & 0.795 & & & \\
\hline L8 & & 0.786 & & & \\
\hline L11 & & 0.650 & & & \\
\hline L22 & & 0.631 & & & \\
\hline L18 & & & 0.797 & & \\
\hline L17 & & & 0.779 & & \\
\hline $\mathrm{L} 23$ & & & 0.710 & & \\
\hline L14 & & & 0.657 & & \\
\hline L24 & & & & 0.670 & \\
\hline L27 & & & & 0.669 & \\
\hline L29 & & & & 0.636 & \\
\hline L30 & & & & 0.617 & \\
\hline L26 & & & & 0.593 & \\
\hline L19 & & & & & 0.736 \\
\hline L16 & & & & & 0.684 \\
\hline L21 & & & & & 0.663 \\
\hline
\end{tabular}
method was used.

After deleting the above five items and re-analyzing the factors, five factors can be obtained in this scale, and the total explanatory variance is $56.509 \%$, which meets the standard of over $50 \%$, and the lowest eigenvalue is 1.869 , which meets the screening standard of over 1 eigenvalue. Table 3 shows that Factor 1 contains 7 questions, Factor 2 contains 5 questions, Factor 3 contains 4 questions, Factor 4 contains 5 questions, and Factor 5 contains 3 questions. In this study, the factors obtained were named as "environmental protection", "fashion", "cost savings", "independent adventure" and "status" according to the meaning of the items contained in them.

\subsubsection{Group Analysis of Consumer Life Style}

According to the analysis of five factors of consumer life style obtained from the above factor analysis, as a basis for group analysis, the k-means clustering population analysis method was adopted. The 353 samples in this study were taken as the total samples for group analysis. After the analysis of life style factors, three kinds of consumer groups were separated, and the scores of three kinds of consumer life style factors were found as shown in Table 6. One Way ANOVA was used to explore whether there were differences between each consumer group and life style factors, and the analysis results showed that they were significant $(p<0.05$ indicates significance). 
Table 6. Summary of consumer life style group analysis.

\begin{tabular}{|c|c|c|c|c|c|c|}
\hline Factor & Group 1 & Group 2 & Group 3 & F Verification & $p$-Value & $<\alpha$ \\
\hline 1. Environmental protection & -0.97209 & 0.43961 & 0.19690 & 99.840 & 0.00 & * \\
\hline 2. Fashion & -0.24184 & -0.27049 & 0.87435 & 51.816 & 0.00 & * \\
\hline 3. Cost savings & -0.50903 & 0.49887 & -0.48067 & 57.796 & 0.00 & * \\
\hline 4. Independent adventure & -0.25842 & -0.03140 & 0.37450 & 9.401 & 0.00 & * \\
\hline 5. Status & 0.39988 & 0.15659 & -0.81418 & 46.073 & 0.00 & * \\
\hline Number of samples & 96 & 176 & 81 & & & \\
\hline Group name & Brand-conscious group & $\begin{array}{l}\text { Environmental and } \\
\text { cost saving }\end{array}$ & Trendy adventurers group & & & \\
\hline
\end{tabular}

Note: ${ }^{*} p<0.05$.

Table 7 reveals that the significance of each factor is 0.00 , and the $p$-value part needs to be less than 0.05 to meet the significant level of discrimination ability, all of which meet the significant level. The higher the positive coefficient, the more attention is paid to this factor, while the higher the negative coefficient, the less attention is paid to this factor. The naming explanation of consumer life style groups is as above, and the following factors and remarkable characteristics of each group are the brand-conscious group, environmental and cost saving group, and trendy adventurers group.

Table 7. Positive and negative trait factors of consumer life style.

\begin{tabular}{lll}
\hline Group Name & Positive Factor & Negative Factor \\
\hline Brand-conscious group & status & green environmental protection, cost savings, \\
$\begin{array}{l}\text { Environmental and cost saving group } \\
\text { Trendy adventurers group }\end{array}$ & $\begin{array}{l}\text { cost savings, green environmental protection } \\
\text { fashion, independent adventure }\end{array}$ & $\begin{array}{l}\text { fashion, independent adventure } \\
\text { status, cost savings }\end{array}$ \\
\hline
\end{tabular}

\subsubsection{Characteristics of Demographic Variables}

As demographic variables also have an impact on consumer life style factors, after group analysis, the demographic variables of the basic data of each group were discussed. This study compiled the relationship between consumer life style group and gender, age, educational level, residential area, monthly income, and occupational category, and used cross-analysis and the Chi-square test to verify whether there are significant differences among groups. The Chi-square test results showed that except for the significant differences in gender, occupation, and purchase intention, the Chi-square values of life style groups in this study were all greater than the 0.05 significant level, indicating no significant difference, as shown in Table 8.

Table 8. Pearson Chi-square test significance.

\begin{tabular}{ll}
\hline Item & Progressive Significance \\
\hline Gender & $0.017^{*}$ \\
\hline Age & 0.673 \\
\hline Educational level & 0.313 \\
\hline Occupational category & $0.033^{*}$ \\
\hline Monthly income & 0.081 \\
\hline Residential area & 0.792 \\
\hline Purchase intention & $0.041^{*}$ \\
\hline Note: ${ }^{*}<0.05$. &
\end{tabular}

Table 8 shows the comparison between the cross-analysis and Chi-square test of gender, age, educational level, residential area, monthly income, occupation category, and purchase intention in consumer life style groups. The following will explain the trait analysis of the three groups in detail: 


\section{(1) Cluster 1: brand-conscious group}

Consumers of this group advocate famous brands very much, think that using famous brands can represent a person's status, and have no concern for environmental protection issues. When consuming, they will take brand knowledge as the first consideration, and pay little attention to price, so they belong to a luxury consumer group. Among the 96 people of this consumer group, most of them are between 25 and 40 years old, and most are male. As for the educational level, most of them attended university/junior college; most of them have a monthly income falling between NTD 30,001 and 50,000. This group has the smallest proportion of students $(10.2 \%)$, and most of the group members are employed office workers; most of them live in the north. From the age distribution, it can be found that most members of this group have jobs, have a stable income, and belong to those who have the ability to control money. Therefore, it can be inferred that the goods purchased by this group must conform to their status to highlight their value, and they have a higher impulse and willingness to buy famous name brand goods than other groups.

(2) Cluster 2: environmental and cost saving group

Consumers of this group are very concerned about the environment and ecology of the earth. They will bring their own shopping bags, water cups, and tableware, give priority to environmental protection in consumption, do not pursue fashion blindly, and have a conservative mindset. They usually pay special attention to discount messages, shop around for the best price, and are cautious about consumption, but are willing to buy green environmental protection products with slightly higher prices. Among the 176 people in this consumer group, most of them are between 18 and 30 years old, and most are male. As for the educational level, most of them attended university/junior college; most of them have a monthly income falling below NTD 15,000. Most of the group members are students, and the proportion of industry and commerce practitioners is significantly higher than the other two groups. Most of them live in the north. In this group, the proportion of consumers who are unwilling to buy if not given a government subsidy is the highest (34\%). The reason for this may be that the age of most consumers in this life stlye group indicates they may be new to the workforce and have limited economic resources. Therefore, for blind and irrational spending, this group is less likely than the other two groups to engage in this behavior.

\section{(3) Cluster 3: trendy adventurers group}

Consumers of this group attach great importance to new fashion trends and innovation, have a mentality of trying new things, dress up carefully to show their fashion tastes, are very independent in personality, do not like to rely on others, have their own opinions on everything, like to engage in challenging works and love dangerous and exciting activities. In terms of consumption behavior, innovative and unique goods are of great appeal to them. There are 81 people in this consumer group, and most of them are male; their age ranges from 18 to 24 years old, and most of them are students; most of the consumers in this age group are college students, and their monthly income falls below NTD 15,000. Although they have no economic advantage, they may pursue popularity due to the influence of online media and peers.

\subsection{Analysis of the Difference of Preference of Electric Scooter Product Attributes among Groups with Different Life Styles}

This study intended to analyze the difference in subjects' preference for electric scooter product attributes. Therefore, the exploratory factor analysis method was first used to simplify 27 questions about the product attributes tested, so as to extract the main factors of the product attributes of Gogoro electric scooters and explore the differences in the degree of value accorded paid to the product attributes among the three consumers' life style groups of Gogoro electric scooters.

The total reliability of the product attribute scale is 0.888 , which is higher than 0.7 , which means that the scale of this study is reliable. The $\mathrm{KMO}=0.860$ and the significance 
of the Pap spherical test was $0.000(p<0.05)$, which reached a significant level, so the data presented were suitable for factor analysis. After passing the verification, the principal component analysis in factor analysis was used to extract common factors. Taking the sum of eigenvalues greater than 1 as the screening condition, the items with low factor load were deleted. Then, factor analysis was carried out again. According to the component matrix behind the rotation axis, the items that do not meet the convergence validity evaluation standard were eliminated, and the exploratory factor analysis was carried out repeatedly after deleting the items, so as to obtain the following results, such as the factor eigenvalues of the product attribute scale after deleting the items in Table 9 and the component matrix behind the rotation axis of the principal component analysis of the product attribute scale after deleting the items in Table 10.

Table 9. Post-axis interpretation variance and cumulative interpretation variance.

\begin{tabular}{llll}
\hline Initial Eigenvalue & & \\
\hline Composition & Eigenvalue & Explained Variance \% & $\begin{array}{l}\text { Cumulative } \\
\text { Interpretation } \\
\text { Variance \% }\end{array}$ \\
\hline 1 & & & 17.858 \\
2 & 4.107 & 17.858 & 29.902 \\
3 & 2.770 & 12.044 & 40.840 \\
4 & 2.516 & 10.938 & 50.963 \\
5 & 2.328 & 10.123 & 59.011 \\
\hline
\end{tabular}

Table 10. Rotating component matrix.

\begin{tabular}{|c|c|c|c|c|c|c|}
\hline \multirow{2}{*}{$\begin{array}{l}\text { Product } \\
\text { Attribute } \\
\text { Question Item }\end{array}$} & \multicolumn{6}{|c|}{ Composition } \\
\hline & 1 & 2 & 3 & 4 & 5 & 6 \\
\hline P19 & 0.772 & & & & & \\
\hline P18 & 0.747 & & & & & \\
\hline P20 & 0.684 & & & & & \\
\hline $\mathrm{P} 13$ & 0.664 & & & & & \\
\hline P14 & 0.658 & & & & & \\
\hline P22 & 0.614 & & & & & \\
\hline P21 & 0.586 & & & & & \\
\hline P6 & & 0.811 & & & & \\
\hline P7 & & 0.784 & & & & \\
\hline P8 & & 0.776 & & & & \\
\hline P9 & & 0.761 & & & & \\
\hline $\mathrm{P} 12$ & & & 0.750 & & & \\
\hline P11 & & & 0.744 & & & \\
\hline P24 & & & 0.643 & & & \\
\hline P15 & & & 0.639 & & & \\
\hline P2 & & & & 0.846 & & \\
\hline P1 & & & & 0.830 & & \\
\hline P3 & & & & 0.774 & & \\
\hline P26 & & & & & 0.767 & \\
\hline P27 & & & & & 0.749 & \\
\hline P25 & & & & & 0.575 & \\
\hline P5 & & & & & & 0.862 \\
\hline P17 & & & & & & 0.709 \\
\hline
\end{tabular}

Retrieval method: Principal component analysis. Rotating axis method: Kaiser normalized maximum variation method was used.

After deleting the above four items and re-analyzing the factors, six factors can be obtained in this scale, with a total explanatory variance of $65.888 \%$, which meets the standard of over $50 \%$, and the lowest eigenvalue is 1.582 , which meets the screening standard of over 1, as shown in Tables 9 and 10 . 
Table 7 indicates that Factor 1 contains 7 questions, Factor 2 contains 4 questions, Factor 3 contains 4 questions, Factor 4 contains 3 questions, Factor 5 contains 3 questions, and Factor 6 contains 2 questions. In this study, the factors obtained are named as "performance", "appearance", "customization", "pricing", "service", and "environmental protection" according to the meaning of the items contained in them.

The purpose of this paper was to explore whether there are significant differences in the importance of six sub-dimensions of electric scooter product attribute factors (performance, appearance, customization, pricing, service, and environmental protection) among the three different consumer life style groups (brand-conscious group, environmental and cost saving group, and trendy adventurers group). In this study, single-factor dependent sample analysis of variance (repeated number analysis of variance) was used to explore the importance of product attribute factors in electric scooter consumers' living groups, and the differences of product attribute factors among different living groups were understood by post-comparison.

(1) The differences of various factors of electric scooter product attributes among the "brand-conscious group"

After statistical analysis, repeated measure ANOVA analysis performed on product attributes for the "brand-conscious group" gave an F value of 52.237, $p<0.05$, which has reached a significant level. Therefore, the null hypothesis that "there is no statistically significant difference in the value of the "brand-conscious group" to product attribute factors" must be rejected. Our results show that 96 consumers who advocate famous brands have significant differences in their attention to the six sub-dimensions of product attributes. Then, each factor of product attribute of the "brand-conscious group" was compared in pairs. After the comparison, it can be found that the brand-conscious group attaches the highest importance to "performance", followed by "service", "pricing", "appearance", and "customization", and "environmental protection".

(2) The differences of various factors of electric scooter product attributes among "environmental and cost saving group"

After statistical analysis, repeated measure ANOVA analysis performed on product attributes for the "environmental and cost saving group" gave an F value is 146.521, $p<0.05$, which has reached a significant level. Therefore, the null hypothesis that "there is no statistically significant difference in the value of the "environmental and cost saving group" to product attribute factors" must be rejected. Our results show 176 consumers of the environmental and cost saving group have significant differences in their attention to the six sub-dimensions of product attributes. Then, each factor of product attribute of the "brand-conscious group" was compared in pairs and was subject to post-comparison, it can be found that the environmental and cost saving group attaches the highest importance to "performance", followed by "service" and "pricing", "environmental protection", "appearance", and "customization".

(3) The differences of various factors of electric scooter product attributes among the "trendy adventurers group"

After statistical analysis, repeated measure ANOVA analysis performed on product attributes for the "trendy adventurers group" gave an F value is 30.692, $p<0.05$, which has reached a significant level in the analysis of product attribute repeat variance of "trendy adventurers group". Therefore, the null hypothesis that "there is no statistically significant difference in the value of the "trendy adventurers group" to product attribute factors" must be rejected. Our results show that 81 trendy adventure consumers have significant differences in their attention to the six sub-dimensions of product attributes. Then, each factor of product attribute of the "trendy adventurers group" was compared in pairs. After the comparison, it can be found that the trendy adventurers group attaches the highest importance to "performance", followed by "service", "pricing", "appearance", and "customization" and "environmental protection". 
(4) The differences in the attributes of electric scooter products among different groups of consumers with different life styles

In order to know whether there are significant differences in the product attributes of electric scooters among different life style groups of consumers, in this study, the factor scores of six product attribute factors (performance, appearance, customization, pricing, service, and environmental protection) and three different life styles (brand-conscious group, environmental and cost saving group, and trendy adventurers group) were used for ANOVA analysis, so as to evaluate and compare the differences of consumers' attention to product attributes in different life styles. The analysis results below showed that the six product attribute factors analyzed are statistically significant, the results of the post-hoc test by Scheffe's method were used to analyze each of the six product attributes and the results are listed as follows.

a. Differences in the importance attached to the "performance" of electric scooters by groups with different life styles

The one-way ANOVA test of "performance" of different life style groups showed that the $\mathrm{F}$ value was 13.753, and the corresponding probability value $p$ was less than 0.05 , which reached a significant level. Then, the Sheffield method was further used for the post-test. From the multiple comparisons of "performance" among different life style groups, it can be found that the "environmental and cost savings group" and "trendy adventurers group" pay more attention to the "performance" of electric scooters than the "brand-conscious group".

b. Differences in the importance attached to the "appearance" of electric scooters by ethnic groups with different life styles

The ANOVA test of "appearance" of different life style groups showed that the F value is 7.162 , and the corresponding probability value $p$ is less than 0.05 , which is significant. Then, the Sheffield method was further used for the post-test. From the multiple comparisons of the "appearance" of different life style groups, it can be found that the "trendy adventurers group" pays more attention to the "appearance" of electric scooters than the "brand-conscious group" and "environmental and cost saving group".

c. Differences in the importance attached to the "customization" of electric scooters by different groups with different life styles

The ANOVA test of "customization" of different life style groups showed that the F value obtained by one-way ANOVA is 3.212 , and the corresponding probability value $p$ is less than 0.05 , which is significant. Then, the Sheffield method was further used for the post-test. From the multiple comparisons of "customization" among different life style groups, it can be found that the "trendy adventurers group" pays more attention to the "customization" of electric scooters than the "brand-conscious group".

d. Differences in the importance attached to the "pricing" of electric scooters by groups with different life styles

The ANOVA test of "pricing" of different life style groups showed that the F value obtained by one-way ANOVA is 10.760, and the corresponding probability value $p$ is less than 0.05 , which is significant. Then, the Sheffield method was further used for postverification. From the multiple comparisons of the "pricing" of different life style groups, it can be found that the "environmental and cost savings group" pays more attention to the "pricing" of electric scooters than the "brand-conscious group" and the "trendy adventurers group".

e. Differences in the importance attached to the "service" of electric scooters by groups with different life styles

The ANOVA test of "service" of different life style groups showed that the F value obtained by one-way ANOVA is 7.608, and the corresponding probability value $p$ is less than 
0.05, which is significant. Then, the Sheffield method was further used for post-verification. From the multiple comparisons of "service" among different life style groups, it can be found that the "environmental and cost saving group" and "trendy adventurers group" pay more attention to the "service" of electric scooters than the "brand-conscious group".

f. Differences in the importance attached to the "environmental protection" of electric scooters by groups with different life styles

The ANOVA test of "environmental protection" of different life style groups showed that the F value obtained by one-way ANOVA is 43.614 , and the corresponding probability value $p$ is less than 0.05 . Then, the Sheffield method was further used for post-verification. According to the ANOVA analysis of "environmental protection" of different life style groups, it can be found that the "environmental and cost saving group" pays more attention to the "environmental protection" of electric scooters than the "brand-conscious group" and the "trendy adventurers group".

\subsection{Consumer Demand Analysis for Electric Scooter Products}

This study investigated the importance of Gogoro consumers' demand for electric scooters. Simple additive weighting (SAW) was used to calculate the weight value of each demand evaluation option. In the SAW algorithm, the score of each scheme was expressed by the sum of the product of each criterion and its relative weights, and the score was used to measure the advantages and disadvantages of the scheme. First, the score of each option was calculated according to the performance value and relative weight of each criterion; then, according to the score size of the options, the priority was evaluated. As shown in Table 11, the top three user demands that the subjects pay most attention to are "1. Commuting", "2. Travel and leisure", and "3. Shopping". The 4th to 10th ones are "4. Work and business use", "5. Environmental protection”, "6. Transporting passengers", “7. Pursue popular trends", “8. Attention seeking”, “9. Building interest group with other riders", and "10. Street racing".

Table 11. Importance ranking of electric scooter user demand.

\begin{tabular}{ll}
\hline User Demands & Ranking \\
\hline Commuting & 1 \\
Travel and leisure & 2 \\
Shopping & 3 \\
Work and business use & 4 \\
Environmental protection & 5 \\
Transporting passengers & 6 \\
Pursue popular trends & 7 \\
Attention seeking & 8 \\
Building interest group with other riders & 9 \\
Street racing & 10 \\
\hline
\end{tabular}

\section{Discussion}

This study aimed to explore the relationship between consumers' life style and product attributes that determine purchasing decisions of electric scooters. Based on the demographics, we defined three life style consumer groups. Then we analyzed the preferences and differences among the three life style groups to the relative importance of specific. Finally, within each product attribute, we compared its relative importance across all three life style groups. This study adopted the self-made research questionnaire on the Investigation of Consumer's Life style and Product Attribute Preferences of Electric Scooters as the research tool and distributed the questionnaire online. After the questionnaires were collected, they were analyzed by various SPSS statistical methods, and the conclusions and suggestions were put forward. The conclusions of this study were divided into the following four detailed descriptions. 
(1) Explore consumers' green consumption behavior for electric scooters. This study took consumers' life styles as the starting point of market segmentation. Expert interviews indicate that consumers' buying decisions for electric scooters can be influenced by many aspects, including pricing, performance, branding, and psychological factors. Among them, the key influencing factors for consumers' purchase of electric scooter products is, according to all experts and scholars, the performance of the product. Product performance must meet the expectations of consumers in order to attract consumers to buy, and secondly, the cooperation and promotion of government policies to subsidize green consumption are of great importance. Although consumers' awareness of environmental protection will affect their willingness to buy electric scooters, the impact is not large. According to the survey, if the government cancels the subsidy, less than half of the consumers intend to replace gas-fueled scooters with electric, which shows that the booming electric scooter market is actually not self-sustaining. If the government withdraws the subsidy, it may cause a wave of impact on the electric scooter market. Therefore, in addition to the pricing factors, it is necessary for government policies to cooperatively promote electric scooter purchase. Additionally, it is necessary to continuously increase the urban infrastructure, such as charging stations, dedicated scooter lanes, and parking spaces, so as to continuously support and promote the development of the electric scooter industry.

(2) Explore the types of consumers' life styles. The results showed that most consumers are between 18 and 29 years old, have a college education, live in the north, and earn NTD 20,001-NTD 40,000 per month. By analyzing and summarizing the results of the questionnaire, it showed several categories of consumers' life styles. The questionnaire of this study consists of $30 \mathrm{AIO}$ scales and 27 product attribute preference scales. Factor analysis and group analysis show that consumer life style can be divided into five types, which are: "green environmental protection", "fashion", "cost savings", "independent adventure" and "status"; and from the life style, it can be divided into three major groups, respectively: "brand-conscious group", "environmental and cost savings group" and "trendy adventurers group".

(3) Explore the relative importance of various factors of electric scooter product attributes among the three different life style groups. All three groups attach the most importance to the "performance" of electric scooters products. Secondarily, they value the "service" and "pricing" of products. All three groups valued "customization" least. In this study, the "environmental protection" of products is one of the least important factors for the brand-conscious group and the trendy adventurers group. However, it is the third most important factor in the environmental and cost savings group, which would be congruent with this life style. The environmental and cost savings group is more concerned about the destruction of the earth's environment and ecology, and its attention to environmentally protective products is far higher than the other two groups.

(4) Within each of the six electric scooter product attributes, its importance to each life style group is compared and ranked. The "brand-conscious" consumers assigned significantly less value to all six product attributes than the other two life syle groups. The "environmental and cost savings group" gives greater value to "pricing" and "environmental protection" than the other two groups, and the "trendy adventurers group" values "appearance" and "customization" more than the other two groups.

Research shows that, at present, on the basis of satisfying consumer demand for electric scooters' performance, the main reason driving the positive development of the electric scooters industry in the market is supportive government policies such as subsidies, instead of the environmental awareness of consumers. This means that in order to maintain or promote the sustainable development of the electric scooters industry, the government needs to continue to promote subsidies and policies that support the electric scooters market according to market conditions to continue to attract consumers to buy electric scooters. Although consumers' awareness of environmental protection is not the main 
reason to drive the development of the electric scooters market, it is also an influential factor that cannot be ignored. Therefore, enhancing consumers' awareness of environmental protection is also regarded as an auxiliary strategy to promote the development of the electric scooters industry.

In regards to the difficult choices between morality and economy when making green consumption decisions, our research results show that consumers choose economy over environmental protection. If we want the sustainable development of the electric scooter industry, the support of government policy plays an indispensable role. Although we can see that the electric scooter market in Taiwan is developing rapidly, considering the above factors, in order to strengthen sales of electric scooters, it is necessary to cultivate and promote awareness of environmental protection targeted to specific life style groups in commercial publicity campaigns.

Our study shows that the consumers of electric scooters can be divided into three different consumer life style clusters, namely, those who prioritize luxury branding, those who care about protecting the environment, and those who value risky trendy adventuresome experiences. Focusing on the performance and performance of electric scooters can help improve the electric scooters industry. To better understand and distinguish different consumer life styles that can be used to positively influence electric car ownership will help the government and educators to achieve environmental sustainability goals. In the increasingly competitive market environment, there is consensus in the industry that improving user experience in service capabilities is an important area in need of innovations in service capabilities. Obtaining accurate user portraits is core to the competitiveness of enterprises $[49,50]$. According to the three different life style clusters of consumers of electric scooters found in this study, further refinement of profiles of target users and providing better service value for the specific target user groups can enhance the ability of enterprises to differentiate their products and compete in user experience. For example, when designing new electric scooters product shapes, they can be designed according to the personalized preferences of three life style groups, so as to appeal to users in each. Likewise, differentiated marketing strategies can be developed for the three life style groups. Ongoing educational research on target consumer life style groups for electric locomotives can refer to the findings of this article as a foundation for further related research.

\section{Conclusions}

Using the electric scooter as an example, this study analyzes and discusses the impact of consumers' life style on users' needs and purchasing decisions. It provides a strategic reference strategy to inform government policies as well as the development of the electric scooter industry. At present, although the research on green consumption has become a hot issue, the electric scooter industry and the government often lack effective strategies to influence target users. From the marketing point of view, this study found that although consumers' awareness of environmental protection will affect their willingness to buy electric scooters, the impact level is not high, and it is still apparently necessary for government policies to support and promote the sales of electric scooters to achieve desired environmental sustainability goals.

Three distinct life style groups have been identified in this study namely, those who prioritize status from luxury branding, those who value the protection of the environment, and those who value trendy adventuresome experiences. The further delineation of the above consumer life style groups will clarify the user portraits for the electric scooter market, improve the detailed classification of consumer life styles, and expand the information about the characteristics of potential users of electric scooters in previous studies. This can provide a significant reference for strategies to improve user experience. These strategies can be key to gaining a competitive advantage, especially in regions such as Taiwan where the electric scooter industry is expanding quickly.

Furthermore, this study shows the relationship between three different life styles groups and the electric scooter product attributes that are important to each group. Among 
the three groups, the brand conscious group valued personal customization the least of all the product attributes. Therefore, electric scooter enterprises may not want to direct limited resources towards design and customization but instead focus on improved product performance and customer service. Surprisingly, even among the environment and cost savings group, the user demands for performance, cost, and service were valued more highly than environmental sustainability. This means that marketing strategies that focus primarily on environmental protection will be of limited value for electric scooter companies. Additionally, because environmental protection was valued least important for the brand conscious and trendy adventurers groups, this may inform public and non-profit environmental agencies of the ongoing need for improved public education and promotion of green consumption. The trendy adventurers group values product appearance and personal customization more than the other two groups. For electric scooter companies, this result may reveal the need to strengthen product design strategies that will appeal more specifically to the values and interests of this life style group.

Compared with other studies on green consumption, our study of potential consumers of electric scooters reveal that at present, governmental subsidies are the main reason driving the development of the electric vehicle market, rather than the awareness or value for green consumption. More importantly, this population of consumers has not been carefully studied in previous studies to explore the relationship between demographic data, life style group characteristics, and their preferences and user needs. The above research results provide value for the strategic development of the electric scooter industry.

The limitation and suggestions of this study are as follows: Although the Gogoro brand electric scooter we used in our study is well-known in Taiwan, compared with the scooter market in Taiwan as a whole, it is still a niche market. Those specifically selected for statistical analysis in our study are people who are interested in buying Gogoro scooters; those who are already Gogoro scooter owners were excluded from our sample population. This study did not attempt to make a statistical analysis of the people who are already electric scooter owners. In further research, as electric scooters become more mainstream in the scooter market, a differentiated analysis of electric scooter owners with different life styles and related strategies for electric scooter products for the scooter market could be explored. After electric scooter ownership becomes more common in the future, follow-up researchers can perform differentiation analyses for distinct life styles groups of Gogoro scooter owners and draw up general design strategies for electric scooter products. Secondly, other product elements such as shape, color, quality, and functionality can be surveyed. This study only focused on consumers' preference for product attributes and did not consider other design elements. Therefore, it is suggested that follow-up researchers can conduct comprehensive research and investigation on other elements of electric scooter designs for companies to obtain data for more detailed users' needs. Finally, due to the use of online questionnaires throughout this study, it is inevitable that there would be an uneven distribution of male/female ratio, age, educational level, occupation, and area of residence. It is suggested that future studies seek to minimize these impacts. It is suggested that future researchers can minimize these differences as much as possible.

Author Contributions: Conceptualization, J.-C.T. and T.-J.Y.; methodology, J.-C.T.; writing—original draft preparation, T.-J.Y.; writing-review and editing, J.-C.T. and X.-H.J. All authors have read and agreed to the published version of the manuscript.

Funding: This research received no external funding.

Institutional Review Board Statement: Not applicable.

Informed Consent Statement: Not applicable.

Data Availability Statement: Not applicable.

Conflicts of Interest: The authors declare no conflict of interest. 


\section{References}

1. Diffenbaugh, N.S.; Burke, M. Global Warming Has Increased Global Economic Inequality. Proc. Natl. Acad. Sci. USA 2019, 116, 9808-9813. [CrossRef] [PubMed]

2. Giorgi, F.; Raffaele, F.; Coppola, E. The Response of Precipitation Characteristics to Global Warming from Climate Projections. Earth Syst. Dyn. 2019, 10, 73-89. [CrossRef]

3. D'Amato, G.; Akdis, C.A. Global Warming, Climate Change, Air Pollution and Allergies. Allergy 2020, 75, 2158-2160. [CrossRef] [PubMed]

4. Testa, F.; Pretner, G.; Iovino, R.; Bianchi, G.; Tessitore, S.; Iraldo, F. Drivers to Green Consumption: A Systematic Review. Environ. Dev. Sustain. 2021, 23, 4826-4880. [CrossRef]

5. Lin, S.T.; Niu, H.J. Green Consumption: Environmental Knowledge, Environmental Consciousness, Social Norms, and Purchasing Behavior. Bus. Strategy Environ. 2018, 27, 1679-1688. [CrossRef]

6. Tirkolaee, E.B.; Hadian, S.; Weber, G.W.; Mahdavi, I. A Robust Green Traffic-Based Routing Problem for Perishable Products Distribution. Comput. Intell. 2019, 36, 80-101. [CrossRef]

7. Qiu, L.-Y.; He, L.-Y. Can Green Traffic Policies Affect Air Quality? Evidence from a Difference-in-Difference Estimation in China. Sustainability 2017, 9, 1067. [CrossRef]

8. Liu, Y.; Tan, J. Green Traffic-Oriented Heavy-Duty Vehicle Emission Characteristics of China VI Based on Portable Emission Measurement Systems. IEEE Access 2020, 8, 106639-106647. [CrossRef]

9. Chu, K.-C.; Xiao, M.-Y. A Study on the Correlation between Breast Cancer and Air Pollution. In Proceedings of the 2017 IEEE/ACM International Conference on Advances in Social Networks Analysis and Mining, Sydney, Australia, 31 July-3 August 2017.

10. Chang, H.-H.; Meyerhoefer, C.; Yang, F.-A. COVID-19 Prevention and Air Pollution in the Absence of a Lockdown. Natl. Bur. Econ. Res. 2020, in press.

11. Su, S.Y.; Liaw, Y.P.; Jhuang, J.R.; Hsu, S.Y.; Chiang, C.J.; Yang, Y.W.; Lee, W.C. Associations between Ambient Air Pollution and Cancer Incidence in Taiwan: An Ecological Study of Geographical Variations. BMC Public Health 2019, 19, 1496. [CrossRef]

12. Lin, Y.-T.; Lin, Y.-C. The Impact Analysis of Traffic and Meteorological Factors on Air Pollution Risk in Taiwan, Taipei City. In Proceedings of the vEGU21, the 23rd EGU General Assembly, Online, 19-30 April 2021.

13. Huang, S.K.; Kuo, L.; Chou, K.-L. The Impacts of Government Policies on Green Utilization Diffusion and Social Benefits-A Case Study of Electric Motorcycles in Taiwan. Energy Policy 2018, 119, 473-486. [CrossRef]

14. Cheng, L.-M. Electric scooter promotion policy in Taiwan. In Energy Management for Sustainable Development; Gokten, S., Kucukkocaoglu, G., Eds.; IntechOpen: London, UK, 2018.

15. Ajanovic, A.; Haas, R.; Schrödl, M. On the Historical Development and Future Prospects of Various Types of Electric Mobility. Energies 2021, 14, 1070. [CrossRef]

16. Farnsworth, D.; Shipley, J.; Sliger, J.; Lazar, J. Beneficial Electrification of Transportation; The Regulatory Assistance Project: Montpelier, VT, USA, 2019; Available online: https:/ / www.raponline.org/wp-content/uploads/2019/01/rap-farnsworth-shipley-sligerlazar-beneficial-electrification-transportation-2019-january-final.pdf (accessed on 14 December 2020).

17. Khanna, T.; Chan, B. Case Study: Gogoro from Electric Scooter to Energy Platform; Harvard Business Publishing: Boston, MA, USA, 2020.

18. Tang, H. Social Media Engagement, Customer Equity, and Repurchase Intention: An Empirical Study of Gogoro in Taiwan. Master's Thesis, National Sun Yat-sen University, Kaohsiung City, Taiwan, 2019.

19. Chen, C. A Study on Competitive Advantage in Electric Motorcycle Industry from Dynamic Resource Perspective-A Case Study of Gogoro. Master's Thesis, National Sun Yat-sen University, Kaohsiung City, Taiwan, 2019.

20. Zhao, X.; Ye, Y.; Ma, J.; Shi, P.; Chen, H. Construction of Electric scooter Driving Cycle for Studying Electric scooter Energy Consumption and Equivalent Emissions. Environ. Sci. Pollut. Res. 2020, 27, 37395-37409. [CrossRef] [PubMed]

21. Kumar, R.R.; Alok, K. Adoption of Electric scooter: A Literature Review and Prospects for Sustainability. J. Clean. Prod. 2020, 253, 119911. [CrossRef]

22. Lin, W.-Y.; Hsiao, M.-C.; Wu, P.-C.; Fu, J.S.; Lai, L.-W.; Lai, H.-C. Analysis of Air Quality and Health Co-Benefits Regarding Electric Scooter Promotion Coupled with Power Plant Emissions. J. Clean. Prod. 2020, 247, 119152. [CrossRef]

23. Lu, Y. A Study on the Impact of the Development of Electric scooter on Independent Workshop in Taiwan. Master's Thesis, National Sun Yat-sen University, Kaohsiung City, Taiwan, 2018.

24. Shiel, C.; do Paço, A.; Alves, H. Generativity, Sustainable Development, and Green Consumer Behaviour. J. Clean. Prod. 2020, 245, 118865. [CrossRef]

25. Vivek, S.D.; Beatty, S.E.; Dalela, V.; Morgan, R.M. A Generalized Multidimensional Scale for Measuring Customer Engagement. J. Mark. Theory Pract. 2014, 22, 401-420. [CrossRef]

26. Ouyang, B.; He, Y. From Traditional Styling to Lifestyle: Design Thinking Perspective of Cultural Collection. In Proceedings of the International Conference on Applied Human Factors and Ergonomics, New York, NY, USA, 25-29 July 2021; Volume 260, pp. $458-465$.

27. Sinicki, A. Lifestyle design. In Thriving in the Gig Economy; Sinicki, A., Ed.; Apress: New York, NY, USA, 2019 ; pp. 151-173.

28. Trencher, G.; Karvonen, A. Stretching "smart": Advancing health and well-being through the smart city agenda. Local Environ. 2019, 24, 610-627. [CrossRef] 
29. Cao, S.; Chen, Y.; Cheng, G.; Du, F.; Gao, W.; He, Z.; Li, S.; Lun, S.; Ma, H.; Su, Q.; et al. Preliminary Study on Evaluation of SMART-Cities Technologies and Proposed UV Lifestyles. In Proceedings of the 2018 th International Conference on Universal Village (UV), Boston, MA, USA, 21-24 October 2018.

30. Chao, S.-M.; Yen, M.; Lin, H.-S.; Sung, J.-M.; Hung, S.-Y.; Natashia, D. Effects of Helping Relationships on Health-Promoting Lifestyles among Patients with Chronic Kidney Disease: A Randomized Controlled Trial. Int. J. Nurs. Stud. 2022, 126, 104137. [CrossRef]

31. Widiyatmoko, F.A.; Pradipta, G.D.; Hudah, M. The impact of physical education on students' active lifestyles. J. SPORTIF J. Penelit. Pembelajaran 2020, 6, 28-37.

32. Xiao, Y.; Romanelli, M.; Lindsey, M.A. A latent class analysis of health lifestyles and suicidal behaviors among US adolescents. J. Affect. Disord. 2019, 255, 116-126. [CrossRef] [PubMed]

33. Trigueros, R.; Cangas, A.J.; Aguilar-Parra, J.M.; Álvarez, J.F.; García-Más, A. No more bricks in the wall: Adopting healthy lifestyles through physical education classes. Int. J. Environ. Res. Public Health 2019, 16, 4860. [CrossRef]

34. Eludoyin, E.O.; Lemaire, X. Work, Food, Rent, Television: The Role of Lifestyles and Experiences on Household Energy Behaviour in Rural Lagos, Nigeria. Energy Res. Soc. Sci. 2021, 71, 101820. [CrossRef]

35. Hadler, M.; Klösch, B.; Schwarzinger, S.; Schweighart, M.; Wardana, R.; Bird, D.N. The multidimensionality of consumption: Energy lifestyles. In Surveying Climate-Relevant Behavior; Hadler, M., Klösch, B., Schwarzinger, S., Schweighart, M., Wardana, R., Bird, D.N., Eds.; Springer International Publishing: Cham, Switzerland, 2022; pp. 93-112.

36. Moline, H.M. Kids in the Grid: The Role of Family Energy Lifestyles in Changing Residential Energy-Use Behaviors. Master's Thesis, Oregon State University, Corvallis, OR, USA, 2019.

37. Saleem, S.B.; Ali, Y. Effect of Lifestyle Changes and Consumption Patterns on Environmental Impact: A Comparison Study of Pakistan and China. Chin. J. Popul. Resour. Environ. 2019, 17, 113-122. [CrossRef]

38. Thompson, C.J. Caring Consumers: Gendered Consumption Meanings and the Juggling Lifestyle. J. Consum. Res. 1996, 22, 388. [CrossRef]

39. Suyanto, B.; Sugihartati, R.; Hidayat, M.; Subiakto, H. Global vs. Local: Lifestyle and Consumption Behaviour among the Urban Middle Class in East Java, Indonesia. South East Asia Res. 2019, 27, 398-417. [CrossRef]

40. Hanawi, S.A.; Saat, N.Z.M.; Zulkafly, M.; Hazlenah, H.; Taibukahn, N.H.; Yoganathan, D.; Abdul Rahim, N.N.; Mohd Bashid N.A.A.; Abdul Aziz, F.A.; Low, F.J. Impact of a Healthy Life style on the Psychological Well-being of University Students. Int. J. Pharm. Res. Allied Sci. 2020, 9, 1-7.

41. Griban, G.P.; Yavorska, T.Y.; Tkachenko, P.P.; Kuvaldina, O.V.; Dikhtiarenko, Z.M.; Yeromenko, E.A.; Lytvynenko, A.M.; Hresa, N.V.; Okhrimenko, I.M.; Ovcharuk, I.S.; et al. Motor Activity as the Basis of a Healthy Lifestyle of Student Youth. Wiadomości Lek. 2020, 73, 1199-1206. [CrossRef]

42. Nugraha, A.K.; Silintowe, Y.B.; Paramita, E.L. Lifestyle Segmentation: Mobile Phone Purchase Vis-À-Vis Consumption Decision. Bus. Theory Pract. 2022, 23, 14-25. [CrossRef]

43. Plummer, J.T. The Concept and Application of Lifestyle Segmentation. J. Mark. 1974, 38, $33-37$.

44. Huang, H.-Z. On the Ocean Writing of Hong-Ji Liao (1995-2007). Master's Thesis, Tamkang University, New Taipei City, Taiwan, 2007.

45. Yeh, C. A Study on the Impact of the Shopping Mall Location and Consumer Lifestyle Have on Consumer Behavior. Master's Thesis, National Chiao Tung University, Hsinchu City, Taiwan, 2002.

46. Yu, C.-H. A Research of the Relationship between Lifestyle and Product Attribute on the Automobile Consumers-A Case Study for Taipei City. Master's Thesis, National Taipei University, Taipei City, Taiwan, 2004.

47. Park, C.W.; Jaworski, B.J.; MacInnis, D.J. Strategic Brand Concept-Image Management. J. Mark. 1986, 50, 135-145. [CrossRef]

48. Chen, Y.-J. Discussion on Product Attributes and Lifestyle Influencing Consumers' Decision Making on Purchasing BehaviorSleepy Product as an Example. Master's Thesis, Da-Yeh University, Dacun, Taiwan, 2005.

49. Xu, J.; Hu, Z.; Zou, J. Personalized product recommendation method for analyzing user behavior using DeepFM. J. Inf. Process. Syst. 2021, 17, 369-384

50. Gao, M.; Zhang, Y.; Gao, Y. Research Progress of User Portrait Technology in Medical Field. In Proceedings of the 2nd International Symposium on Artificial Intelligence for Medicine Sciences, Zhengzhou, China, 29-31 October 2021. 